\title{
Kedaulatan teritorial negara: kepentingan material dan nilai simbolik
}

\author{
State's territorial sovereignty: material interest and symbolic value
}

\author{
I Gede Wahyu Wicaksana \\ Departemen Hubungan Internasional, Fakultas Ilmu Sosial dan Ilmu Politik, Universitas \\ Airlangga, Surabaya \\ Jalan Airlangga 4-6 Surabaya 60286, Indonesia \\ Telephone +62315011744 \\ E-mail: wahyu.wicaksana@gmail.com
}

\begin{abstract}
This article discusses state's rights ofterritorial sovereignty, aimed at juxtaposing both the components of material interest and symbolic value. Arguably, states are supposed to be the legitimate owner of the rights of territorial sovereignty, as comprising jurisdiction authority, the right to benefit from natural resources, and control over border. This line of reasoning is consistent with the contemporary socio-political conception expressed by, for example David Miller. Its intellectual explanationshave, at first, been rendered by the statist theory drawn upon three tendencies of utilitarian argument, Kantian and Lockean philosophy. The nationalist theory, however, comes to revise the statist one. To conclude, the article presents some research agendas significant and salient for developing theory of state's sovereignty in the expanding international system.
\end{abstract}

Keywords: state, territorial sovereignty, statist theory, nationalist theory

\begin{abstract}
Abstrak
Artikel ini menelaah teorisasi mengenai hak kedaulatan teritorial negara, dengan maksud untuk menampilkan dua komponen; kepentingan material dan nilai simbolik secara bersama-sama. Negara diasumsikan sebagai pemilik hak kedaulatan teritorial yang absah, terdiri atas kekuasaan yurisdiksi, kewenangan mengelola sumber daya/kekayaan alam, dan kontrol terhadap wilayah perbatasan. Corak argumentasi yang diketengahkan konsisten dengan konsepsi sosiopolitik kontemporer sebagaimana diekspresikan oleh David Miller. Pada awalnya, penjelasan intelektual hak kedaulatan teritorial negara disediakan oleh teori statis yang meliputi tiga aliran pemikiran filosofis, yakni utilitarian, Kantian dan Lockean. Kelemahan teori statis direvisi dalam teori nasionalis. Sebagai simpulan disampaikan beberapa agenda riset ke depan yang memiliki signifikansi dan relevansi untuk pengembangan teori mengenai kedaulatan negara dalam sistem internasional yang sedang mengalami ekspansi.
\end{abstract}

Kata kunci: negara, kedaulatan teritorial, teori statis, teori nasionalis

\section{Pendahuluan}

\section{Negara dan kedaulatan teritorial: pengantar diskursus teoritis}

Tujuan tulisan ini adalah mengembangkan teorisasi yang mengkombinasikan elemen normatif/simbolik dan rasional/material dalam diskursus hak kedaulatan teritorial yang dimiliki oleh entitas negara sebagai aktor primer politik internasional. Pertanyaan pokok yang diajukan adalah apakah yang dimaksud dengan hak kedaulatan teritorial negara, dan apakah yang menjadi justifikasi epistemologi sekaligus aksiologi eksistensi kedaulatan teritorial negara dalam sebuah ruang geografi. Walaupun pelbagai literatur hukum internasional dan politik global telah membahas mengenai 
definisi, etiologi dan ontologi kedaulatan teritorial sebagai otoritas mutlak negara (semisal karya Branch 2011:1-36, Valeriano \& Benthuysen 2012: 1165-1189), namun kedua pertanyaan di atas terus mengemuka. Ilmuwan politik dan hukum internasional -khususnya generasi liberal pasca Perang Dingin- biasanya menanyakan mengapa ' $k i t a$ ' wajib mempercayai kebenaran pengertian negara yang mempunyai kekuasaan terhadap wilayah-wilayah spesifik di muka Bumi? Lalu siapakah yang berdaulat di tempat-tempat tidak berpemerintahan, tidak adakah alternatif selain negara berdaulat? Apakah mungkin untuk membangun sebuah otoritas yang tidak berkoneksi dengan teritori? (Clunan \& Trinkunas 2010, Enabulele 2010:407-424, Sandelind 2015:487-507, Vandengeest \& Unno 2012: 358-367). Dalam konteks inilah, penulis mengangkat persoalan konseptual hak kedaulatan teritorial, serta bermaksud membela validitas maupun legitimasi negara berdaulat dalam teritori yang berhasil dikontrol. Perlu untuk membedakan konsentrasi diskusi di sini dengan tema diskursif lain terutama supaya wacana kedaulatan teritorial negara dengan negara teritorial itu sendiri. Perihal negara teritorial tidak dibicarakan.

Selain signifikansi secara intelektual, mengulas hak kedaulatan teritorial memiliki relevansi praktis dalam tiga situasi aktual. Pertama, ketika hak kedaulatan teritorial menjadi obyek perebutan antara pemerintah pusat dan kelompok sekesionis/pemisahan diri yang hendak membentuk negara baru. Yang menjadi masalah ialah apakah tuntutan kelompok separatis atas bagian wilayah negara bisa diterima manakala seluruh warga negara merasa memiliki tempat tersebut. Kasus pembentukan negara Timor Leste melalui referendum tahun 1999merupakan contoh dari situasi demikian (Hainsworth 2000:39, Lee 2015). Kedua, hak kedaulatan teritorial kerap menjadi persoalan bila berkenaan dengan keberadaan sumber daya alam di suatu area. Pertanyaan yang muncul ialah mengapa hanya kelompok komunitas atau otoritas negara tertentu saja yang berhak atas kekayaan alam, mengapa tidak menjadi milik seluruh warga dunia yang kemudian akan membagi manfaat secara distributif melalui mekanisme antarnegara (Reuveny et al. 2011: 701). Banyak kejadian konflik internasional yang bermula dari klaim-klaim sepihak atas teritori yang kaya bahan tambang, mineral. Ironis bahwa sengketa sumber daya alam lebih sering diselesaikan dengan kekuatan militer disertai dengan imperialisme/penguasaan wilayah negara lain. Ketiga, kedaulatan teritorial masih terganjal oleh masalah imigrasi dan kontrol terhadap imigran. Di era globalisasi kian marak agenda-agenda sosial bernuansa kosmopolitanisme yang meyakini Bumi adalah milik semua orang yang mendiaminya. Lantas mengapa harus ada kewenangan untuk mengeksklusi individu-individu dari sebuah wilayah hanya karena mereka tidak mendapat izin untuk tinggal di sana dari pemerintah setempat. Bagi para kosmopolitan, negaralah yang semestinya meminta izin untuk menjalankan kedaulatan kepada penduduk yang memiliki wilayah (Kwok-bun \& Wai-wan 2010: 696-699).

Ketiga situasi aktual di atas membentuk argumen yang dielaborasi dalam tulisan ini, yakni hak kedaulatan teritorial memang merupakan kelengkapan substantif suatu negara, akan tetapi sifatnya derivatif, negara melakukan fungsi sebagai penerus hak kedaulatan teritorial yang diberikan oleh warga negara secara kolektif. Jadi pemegang kedaulatan yang utama adalah individu warga negara yang menugaskan kepada negara dalam relasi kontraktual untuk memakai kewenangan mengatur wilayah hukum, mengelola sumber daya alam, serta mengontrol lalu lintas migrasi di dalam teritori nasional. Pada dasarnya sebuah teritori memiliki tiga komponen yang saling terhubung triangular; sebidang tanah, sekelompok individu yang tinggal di tempat itu, dan institusi politik yang memerintah orang-orang yang mendiami tanah dimaksud. Dengan cara pendefinisian ataupun argumentasi seperti di atas, pasti akan muncul pertanyaan apakah yang menjustifikasi negara sebagai institusi politik, atau institusi politik non-negara, untuk mendapat legitimasi guna mengklaim hak kedaulatan teritorial di suatu tempat? Apakah institusi politik memperoleh kewenangan teritorial secara langsung, atau tidak langsung, dari komunitas yang diperintah?

Jawaban tergantung pada perspektif teoritis yang dirujuk dalam melihat korespondensi politis dan legal antara negara sebagai institusi politik dengan individu/kelompok individu yang menghuni sebuah teritori. Secara umum dikenal dua paradigma, yaitu teori statis dan teori nasionalis. Dalam artikel ini diperkenalkan dan untuk dieksplorasi lebih detil, kedua teorisasi yang menampilkan fitur argumen kombinasi - bisa juga disebut ekuilibrium - antara kepentingan material dan nilai simbolik. Untuk itu terlebih dahulu perlu diuraikan apakah yang dimaksud dengan hak kedaulatan teritorial. 
Ilmuwan politik internasional seperti David Miller (1995, 2012, 252-268) menjelaskan hak kedaulatan teritorial terdiri atas tiga unsur, yaitu kedaulatan hukum, ekonomi dan perbatasan. Ilmuwan lain, Anna Stilz (2011:572-607), mengatakan hak kedaulatan teritori sebuah negara terdiri dari lima pilar, yakni kedaulatan politik, budaya, ekonomi, perbatasan dan hukum. Gagasan Miller dan Stilz mengarah kepada suatu pengertian yang hampir sama tentang esensi hak kedaulatan teritorial. Mereka sekaligus mengafirmasi posisi bahwa hanya negaralah yang berhak untuk menyandang keistimewaan teritorial. Pertama, negara yang berdaulat dalam teritori tertentu memiliki hak untuk membuat kaidah hukum dan melaksanakan aturan main menurut hukum kepada siapa pun yang berada di wilayahnya, hak ini disebut juga sebagai kedaulatan yurisdiksi. Inheren dalam kewenangan yurisdiksi ialah kewajiban aktor eksternal untuk tidak mendirikan lembaga hukum, ataupun menerapkan produk hukum tandingan di dalam wilayah negara berdaulat. Atas nama hak yurisdiksi negara boleh menggunakan kekerasan fisik untuk menindak para pelanggar hukum nasional yang berlaku. Kedua, hak negara untuk mengatur dan memanfaatkan seluruh sumber daya/kekayaan alam yang terkandung di dalam, dan dapat diekstrak dari perut bumi yang menjadi teritorinya. Ketiga, negara memiliki otoritas penuh guna mengawasi dan meregulasi arus keluar masuk barang, jasa dan manusia di wilayahnya.

Ketiga hak teritorial di atas tentu saja tidak perlu dipahami secara terpisah. Hak yurisdiksi berkaitan langsung dengan hak manajemen kekayaan alam, dan kontrol perbatasan. Yurisdiksi memang melingkupi aktivitas manusia, dan manajemen sumber daya alam berkisar pada komponen material. Tetapi koneksi keduanya jelas dan tegas dalam kewenangan negara untuk mengelola proses eksploitasi dan redistribusi manfaat kekayaan alam. Negara berkewajiban dan berhak untuk mencegah pihak asing yang hendak mengambil sumber mineral di wilayah nasional. Hak pengelolaan kekayaan alam mirip dengan property right, walaupun yurisdiksi tidak berarti sama dengan property right. Demikian pula yurisdiksi sebagai elemen fundamental hak kedaulatan teritorial terwujud dalam kewenangan untuk mencegah, mengadili dan mendeportasi imigran ilegal - aktivitas serupa dapat dikenakan terhadap barang - yang masuk ke wilayah negara berdaulat. Namun perlu diklarifikasi bahwa hak ini berbeda dengan agenda pertahanan negara, seperti perang dan diplomasi, terhadap agresi dari luar, sebab yang dicakup oleh yurisdiksi ialah subyek, obyek dan kegiatan di dalam teritori negara saja, dan tidak untuk menjangkau perilaku aktor eksternal yang beroperasi di luar negeri.

\section{Teori statis: utilitarian, Kantian dan Lockean}

Teori statis klasik mengenai keabsahan negara sebagai pemangku hak kedaulatan teritorial, seperti disarikan oleh Richard Foley (2007:21-23), menyebutkan bahwa suatu negara mendapatkan kedaulatan dalam suatu wilayah karena ia mampu menciptakan dan mempertahankan tertib sosial, dan meningkatkan kesejahteraan hidup penduduk yang tinggal di area kekuasaan negara bersangkutan. Cara berfikir ini disebut juga teori negara utilitarian. Walaupun klaim utilitarian bisa dengan mudah diterima sebab dalam dunia modern, negara menjadi satu satunya institusi terorganisir yang mampu menegakan tatanan masyarakat, ada kebingungan yang mengemuka khusus menyangkut seberapa besar ukuran negara yang secara efektif akan dapat membina orde sivil. Ada yang berpendapat bentuk negara kecil (small state) lebih efektif daripada negara besar, dan karena itu negara harus dibagi menjadi unit-unit yang lebih kecil dalam konteks struktur maupun teritori, sehingga kontrol sosial lebih mudah diterapkan (Lee \& Smith 2010:1099-1101). Di sisi lain, penganut gagasan empire state menolak asumsi teori small state. Menurut teori empire state, negara-negara yang terpisah-pisah sebaiknya dipersatukan oleh satu negara kuat dan besar, dianeksasi, supaya tercipta sistem bernegara yang lebih kokoh dan stabil (McCornick 2007). Berikutnya mungkin akan ada pendapat mengenai suatu negara yang dapat mengklaim hak kedaulatan teritorial karena menganggap perfomanya dalam menjamin tertib sosial lebih superior dibandingkan negara rival.

Satu hal yang terlewatkan oleh versi utilitarian teori statis ialah konsiderasi yang menghubungkan eksistensi negara dengan teritori khusus. Jalan keluarnya antara lain yang telah dirumuskan oleh Dudley Knowles (2001:45) yakni melalui pemberian legitimasi tambahan kepada pemerintahan negara berdaulat untuk menguasai penduduk lokal di wilayah bersangkutan. Gagasan ini menyiratkan gaya filsafat politik Kantian yang cukup kental dengan dua karakteristik; 1) negara yang mampu membangun tertib sosial dan menegakkan keadilan sosial menurut standar yang cukup tinggi, dan 2) kehadiran negara merepresentasikan identitas kolektif kelompok individu di dalam wilayah yang 
dikontrol (Kaufman 1999: 4-7). Revisi Kantian memberi sumbangan pemikiran teori statis khususnya dalam menanggapi kontroversi kolonialisme dan separatisme sebagai representasi aspirasi penduduk lokal. Kolonialisme jelas tidak mewakili aspirasi penduduk wilayah jajahan, biarpun mereka menikmati tertib sosial dan promosi kesejahteraan. Pada kasus tertentu, gerakan separatis mungkin merupakan manifestasi keinginan dan identitas masyarakat lokal, namun perlu diingat bahwa koneksi antara negara/institusi politik dengan penduduk yang diwakili diterapkan tidak dengan cara otoriter. Akhirnya, teori statis Kantian menyatakan bahwa negara memiliki hak kedaulatan teritorial karena berhasil memperoleh mandat dari penduduk yang diwakili. Ini berarti ada kontradiksi internal dalam konteks negara bukan pemilik utama kedaulatan teritori; sesuatu yang dicari tahu melalui perspektif utilitarian.

Anna Stilz dalam bukunya Nation, State, and Territory (2011:154-166) mencoba untuk merespon kesenjangan antara harapan dan konstruksi teori utilitarian dengan mengusulkan agar individu yang mendiami suatu wilayah, yang diwakili oleh negara, dilihat cukup sebagai pemilik hak untuk tinggal (the right of occupancy) dan hak untuk menjadi bagian dari penduduk (residence). Hak ini tentu saja kurang memberatkan apabila dibandingkan dengan tuntutan hak kedaulatan teritorial secara utuh. Pertanyaannya bilamana individu mempunyai hak untuk bermukim? Stilz (2011:191-194) menjelaskan ada tiga kriteria; 1) seseorang yang tinggal di area secara terus menerus hingga sekarang, serta berhasil memberdayakan wilayah yang ditinggali; 2) aturan legal di wilayah tempat tinggal dijadikan referensi untuk membentuk struktur hubungan sosial; dan 3) keberadaan individu atau pun kelompok baru di suatu tempat tidak mengakibatkan penyingkiran komunitas lama dari habitat mereka. Prasyarat yang ketiga ditujukan untuk mendelegitimasi hak kedaulatan teritorial yang diakui oleh para agresor asing yang melalui pemaksaan atau kekerasan bersenjata membuat struktur hubungan, tujuan dan pola sosial setelah mengusir warga lokal dari rumah mereka.

Posisi argumentatif Stilz tidak bisa mengatasi persoalan turunan yang misalnya muncul pada pemukiman di mana individu-individu yang berada di sana dinilai secara salah walaupun mereka tidak pernah terlibat dalam tindakan yang patut disalahkan. Kritik ini terbukti pada label yang diterima oleh keturunan dari para penakluk wilayah dan pendiri kolonialisme. Mereka dapat memenuhi seluruh ketentuan untuk mendapatkan hak tinggal, dan kemudian negara yang mewakili pun punya hak kedaulatan teritorial. Kasus yang juga tidak bisa merujuk pada teori Stilz ialah bila di suatu wilayah terjadi pembasmian etnik yang dilakukan oleh milisia yang berasal dari salah satu etnik tertentu yang telah hidup berdampingan dengan etnik-etnik lainnya. Etnik yang selamat kemudian pergi ke wilayah lain dan mengklaim hak untuk tinggal di sana, selanjutnya negara yang merepresentasikan mereka pun terlegitimasi untuk menerapkan kedaulatan teritorial. Dua pengecualian ini mengindikasikan kalau hak untuk tinggal yang boleh diberlakukan bagi kelompok individu tidak cukup lengkap dan kuat buat dijadikan sebagai dasar penetapan hak kedaulatan teritorial negara yang mewakili warga negara.

Baik pendekatan teoritis utilitarian maupun posisi yang lebih analitis dari Stilz mengenai justifikasi etiologis hak kedaulatan teritorial negara mengilustrasikan fakta berorientasi pada masa kini, dalam konteks kedua pendekatan hanya mengkonfirmasi klaim negara atas kedaulatan teritorial berdasarkan pada kemampuan pemerintah untuk memenuhi standar kinerja dan legitimasi formal. Masa lalu tidak menjadi ukuran signifikan, kecuali ditemukan bukti konkrit yang menjelaskan kebijakan negara di masa lampau berimplikasi secara langsung dan nyata terhadap masa depan komunitas yang berada dalam yurisdiksi. Kemudian muncul pertanyaan apakah mungkin untuk mengkonstruksi sebuah teori kedaulatan teritorial yang tetap terpusat pada aktor negara, namun mampu berwawasan historis yang konsisten, atau paling tidak sebuah wacana epistemologi kedaulatan teritorial yang mengizinkan kejadian masa silam untuk menjadi satu bagian referensi standar legitimasi hak istimewa negara terhadap penduduk dan area saat ini. Usaha demikian telah dilakukan oleh misalnya Cara Nine (2008:142) yang berargumen “...on a Lockean theory of desert claims to land, states can come to deserve rights to land'. Nine mengembangkan argumentasi dengan mengusulkan relasi antara negara sebagai institusi formal yang menjalankan kekuasaan dan memonopoli kewenangan dengan individu masyarakat yang bernaung di bawah yurisdiksi pemerintahan. Menurut Nine (2008: 159-160) negara harus dipandang sebagai "...at least in part, the manifestation of the coordinated efforts of individual 
members of the state". Karenanya, bagi Nine (2008: 164) mayoritas nilai yang terdapat dalam suatu wilayah yang diduduki negara berasal dari ide, tindakan dan capaian individu anggora negara yang bersangkutan. Teori Nine menunjukkan ambigu, manakala dihadapkan pada pilihan siapa yang sesungguhnya menjadi pemegang hak kedaulatan atas teritori; negara atau masyarakat.

Teorisasi yang mengkaitkan historisitas - perfoma negara di masa lalu - dan hak untuk berdaulat pada teritori saat ini bisa jadi koheren secara konseptual. Tetapi posisi seperti teori Nine cenderung tidak sensitif terhadap kondisi-kondisi yang telah mengubah nilai asal ciptaan lembaga formal dulu dan faktor-faktor determinan kinerja negara sekarang. Ambil contoh Inggris ketika menjajah Malaysia pada awal abad ke-21 telah membangun sistem pendidikan modern yang bagus untuk penduduk di sana, sehingga menghasilkan pranata edukasi Malaysia yang unggul sekarang. Dengan itu apakah Inggris punya legitimasi untuk mengklaim hak kedaulatan teritorial atas Malaysia, dan jawaban yang tersedia pastilah tidak. Legitimasi negara pun relatif terhadap dinamika sosial. Sebuah negara teokrasi yang di masa lalu menikmati legitimasi besar dari masyarakat yang religius, mungkin akan mengalami degradasi legitimasi karena penduduk muda yang semakin sekuler. Kehadiran kelompok sekesionis juga berarti kelunturan legitimasi negara kesatuan di teritori yang dituntut untuk dipisahkan. Dengan demikian, biarpun ketiga varian teori statis; utilitarian, Kantian dan Lockean dikombinasikan, masih terdapat pelbagai kelemahan yang secara kritis merongrong justifikasi negara sebagai pengampu utama hak kedaulatan teritorial.

\section{Teori nasionalis: kepentingan material dan nilai simbolik}

Telaah terhadap teori statis memberikan sebuah pemahaman bahwa tidak tepat bila memperlakukan negara sebagai satu-satunya pemilik atau pemegang hak kedaulatan teritorial yang absolut. Argumentasi teoritisi statis cenderung pragmatis karena hanya meninjau kelayakan negara sebagai pemangku kedaulatan teritorial atas dasar fakta kekinian, yakni parameter kinerja serta legitimasi legal formal. Sepintas lalu sudut pandang pragmatis statis memang sukses dalam mengetengahkan epistemologi yang memuat identifikasi kondisi-kondisi yang dibutuhkan guna menjustifikasi hak kedaulatan teritorial negara, namun pandangan demikian kurang sensitif dan diskriminatif terhadap faktor latar belakang kesejarahan formasi negara. Argumen historis yang diajukan demi penyempurnaan teorisasi statis pun kurang memiliki kekuatan persuasi yang memadai, walaupun basis rekam jejak masa lalu negara yang dijadikan referensi telah memperhatikan aspek diskriminasi positif. Oleh sebab itu perlu untuk mengulas kerangka berfikir alternatif yang menempatkan individu/kelompok individu warga negara sebagai pemegang mutlak hak kedaulatan teritorial, dengan asumsi dasar bahwa negara yang menjalankan hak kedaulatan teritorial dianggap sebagai perwujudan yang absah dari kehendak rakyat. Karena itu harus dibuat tiga agenda krusial; 1) penjelasan mengenai hal-hal apa saja yang dapat mendukung kapabilitas individu warga negara untuk memiliki hak kedaulatan teritorial; 2) apa yang secara empiris bisa menghubungkan antara individu warga negara dengan kedaulatan teritorial; dan 3) eksplanasi yang secara substantif akan dapat membedakan hak kedaulatan teritorial dalam konteks kepemilikan individual dengan jenis hak lain seperti hak bermukim.

Pertanyaan yang pertama memiliki arti penting sebab usaha teorisasi untuk ranah interaksi negara dan individu diarahkan pada kesimpulan jika hak kolektif lebih bermakna daripada hak yang didefinisikan sesuai kepentingan agregatif individu. Hak kolektif haruslah bersifat stabil, dan oleh karenanya diperlukan sebuah agensi transhistoris yang akan mampu berperan sebagai pembawa hak kedaulatan teritorial dari generasi ke generasi tanpa memerlukan intervensi struktur negara. Kelompok yang mampu menjalankan tugas transfer intergenerasi harus pula memiliki identitas yang bisa ditransmisikan, sehingga anggota baru akan secara otomatis terikat oleh identitas lama melalui pemahaman yang sama mengenai asal usul kelompok (Rutter \& Tienda 2005: 22-25). Dengan kata lain, hak kolektif tidak bisa diwariskan dalam kelompok yang terbentuk hanya karena simbiosis mutualisme antar anggota. Identitas untuk kolompok berfondasi kerja sama saling menguntungkan cenderung bersifat temporal; tidak bisa berlaku identik dari waktu ke waktu, apalagi bila landasan kohesivitas antar sub-kelompok telah berubah. Kandidat yang paling memenuhi syarat buat semua kebutuhan tersebut ialah bangsa (nation) dan penduduk asli (indigenous people). Kedua jenis pengelompokan memiliki ciri yang diharapkan; identitas bersama, kemampuan transhistoris, 
pembagian peran sosial yang jelas, nilai dan norma yang stabil, dan koneksi nyata dengan suatu wilayah geografi, yang semuanya reliabel untuk askripsi hak kedaulatan teritorial (Etherington 2010:1818-1821). Tetapi kedua jenis kelompok terlibat dalam sengketa teritorial yang sengit - bersifat laten, seperti antara 'Bangsa Australia' dan penduduk asli Aborigin.

Lanjut ke isu kedua, bagaimana cara agar kelompok seperti disyaratkan di atas berhasil mendapat hak kedaulatan teritori. Jawaban pasti bukan penaklukan, sebab hal itu berpotensi menimbulkan masalahmasalah yang mengganggu di kemudian hari, misalnya insurgensi, iredentisme dan separatisme. Solusinya ialah bermukim di wilayah tertentu dalam waktu lama agar terbangun suatu relasi transformatif dengan tempat (beserta kelompok yang sudah tinggal lebih dahulu. Proses ini akan diikuti oleh transformasi material dan simbolik dalam pelbagai proporsi. Wilayah yang diokupasi bertambah nilai material karena kehadiran pembangunan lahan pertanian, pembukaan areal pertambangan, industri dan infrastruktur perekonomian seperti jalan raya, pelabuhan dan tidak ketinggalan instalasi pertahanan militer. Dari aspek simbolik, penduduk yang mendiami suatu tempat akan memberi makna lewat kejadian-kejadian penting sepanjang sejarah kelompok mereka; misalnya perang, prasasti dan yang paling sering dibicarakan ialah peristiwa ritual kebudayaan (Smith 1999: 149-159). Wilayah menjadi bernilai bagi kelompok karena secara material merupakan bagian dari, dan terlebih lagi memiliki sumber daya untuk menunjang, usaha peningkatan taraf kehidupan fisik dan kultural mereka, dan nilai simbolik yang mana kelompok memiliki ikatan emosional dengan tanah yang didiami. Dua komponen inilah yang harus dijadikan referensi oleh kelompok luar untuk menghormati eksistensi penduduk lokal, karena jika mereka kehilangan wilayah berarti pula kehilangan aspek material dan simbolik bagi keberlangsungan identitas kolektif.

Klaim kelompok atas kedaulatan wilayah tentu tidak berlaku, dan tidak memiliki standar, secara universal. Suatu kelompok yang telah sukses mempromosikan nilai ekonomis tanah yang ditinggali dan menambahkan nilai simbolik memang berhak untuk menuntut kedaulatan teritorial, dengan patokan standar budaya yang unik. Di tengah masyarakat internasional yang plural secara budaya, tidak ada standar kultural yang menjadi referensi tunggal bagi semua komunitas, bangsa dan negara. Oleh sebab itu, tuntutan kedaulatan teritorial bersifat terbatas; satu standar budaya tidak dapat dijadikan acuan untuk yang lain (Austin-Smith 2003: 39). Aplikasi kedaulatan teritorial oleh kelompok juga mengandung bias dalam hal ini negara modern yang mentransformasi tanah menjadi ekonomi industrial, yang secara konvensional didefinisikan sebagai keberhasilan pembangunan, ternyata berlawanan dengan aspirasi penduduk asli yang mengedepankan keutuhan alam peninggalan nenek moyang mereka; fenomena yang memperlihatkan pertarungan antara modernitas dan lokalitas pembangunan (Gillette et al. 2005). Sampai di sini argumen material untuk justifikasi hak kedaulatan teritorial kelompok bersinggungan dengan teori statis Lockean, terutama jika dipakai untuk membenarkan kedaulatan berdasarkan atas siapa yang lebih unggul dalam meningkatkan produktivitas tanah. Bangsa-bangsa penjajah pernah menyalahgunakan garansi teoritis Lockean untuk menanggalkan kepemilikan penduduk asli terhadap tanah mereka (Moore 1998:147-148). Argumen kolonial tentu tidak perlu diikuti, karena esensi kedaulatan teritorial ialah, sebagai contoh, kelompok yang berhasil membangun perkebunan di sepetak tanah berhak atas buah hasil panen, dan boleh mewariskan kepada anak cucu mereka.

Masih diperlukan klarifikasi melalui identifikasi elemen-elemen peningkatan nilai simbolik teritori. Ada perbedaan antara nilai universal dan nilai spesifik menurut budaya tertentu. Nilai universal menyangkut kondisi-kondisi standar dan kebutuhan hidup yang dimiliki serta dibagi secara bersamasama oleh berbagai kelompok. Apabila pengertian ini disepakati berarti apa pun perubahan yang mengindikasikan perbaikan kapasitas masyarakat untuk mencapai kondisi standar dan kebutuhan pokok disebut sebagai nilai universal (Raz 2001:3). Contohnya ialah pengolahan lahan pertanian, pembangunan drainase, sistem kesehatan, pembasmian penyakit menular dan lain sebagainya yang menunjukkan jenis-jenis aktivitas umum yang dilakukan berbagai anggota masyarakat demi kualitas kehidupan yang lebih tinggi. Sedangkan nilai spesifik berdasarkan orientasi kultural adalah luaran atau hasil aktivitas yang hanya bernilai untuk kebutuhan internal suatu kelompok masyarakat. Sifat kegunaan nilai ini sempit, dan karenanya wajar jika kelompok dengan perangkat budaya berbeda tidak menganggap penting sama sekali hanya karena mereka tidak membutuhkan. Aspek yang membentuk 
nilai partikular bisa saja berasal dari referensi universal seperti agama, namun secara praktis melibatkan pandangan hidup dan persepsi situasional yang terbatas (Baeker 1997: 38-39). Contohnya, minuman beralkohol bagi kelompok yang tinggal di wilayah bertemperatur dingin merupakan bagian cara hidup mereka agar dapat beradaptasi dengan lingkungan. Sementara itu penilaian kelompok lain yang menerapkan aturan keagamaan yang kuat barangkali akan negatif terhadap alkohol.

Pembedaan antara nilai universal dan nilai partikular dengan jelas mengarah pada proposisi bahwa argumentasi material akan lebih kuat bila kelompok yang mengklaim hak kedaulatan teritorial menambahkan nilai universal terhadap sebidang tanah yang diduduki. Misalnya, suatu kelompok menciptakan sistem pertanian yang membuat kesuburan tanah tempat tinggalnya semakin tinggi, sehingga produktivitas teritori tersebut juga semakin besar. Analog, hak kedaulatan teritorial bisa pula dituntut oleh kelompok yang menambahkan nilai kultural spesifik kepada tanah tempat mereka tinggal, dengan catatan nilai universal tidak dirongrong oleh karena tindakan destruktif. Sebagai contoh, kelompok yang mengotori tanah dengan sampah demi memenuhi kepentingan kultural tidak berhak untuk berdaulat di areal yang dicemari, sedangkan kelompok lain yang menggunakan tanah itu untuk menjalankan kewajiban budaya dengan tanpa menimbulkan polusi berhak atas kedaulatan teritorial di sana. Kelompok yang kedua memilih cara mengklaim kedaulatan teritorial melalui promosi atribut kultural tanpa mendegradasikan nilai universal yang sudah mereka konstruksi. Memelihara nilai-nilai universal yang terdapat dalam sebuah wilayah dalam situasi normal, menurut Allan Buchanan (2004: 45-46), merupakan metode untuk memperkuat legitimasi internal, sekaligus melemahkan klaim pihak luar yang hendak menguasai tanah dengan kepentingan pendayagunaan nilai universal secara lebih efektif.

Dengan perspektif nilai material seseorang dan kelompok memang dapat menyediakan alasan untuk kepentingan terhadap sebidang tanah. Tetapi masalah empiris lebih sulit diatasi daripada konseptual. Eksplanasi nilai material universal masih belum cukup andal untuk merespon pertanyaan seperti; apakah semua aktivitas pendukung produktivitas tanah yang telah dilakukan sebuah kelompok akan benar-benar mendatangkan nilai universal dalam waktu yang lama. Pertanyaan ini relevan ketika ada keraguan soal hak kedaulatan teritorial yang dinikmati turun temurun oleh generasi yang secara fisik tidak ikut andil dalam membesarkan nilai universal sebuah wilayah (Simmons 2001:303). Jawaban dikemukakan oleh pendukung teori nasionalis, seperti Leif Wenat (2008:14-17), bahwa klaim itu pun bermasalah karena pengamat tidak boleh membedakan generasi pemilik hak kedaulatan teritorial secara diskrit; generasi yang lebih tua mampu menciptakan kemajuan untuk obyek nilai tertentu, dan bukan yang lainnya, sehingga apa yang diperoleh anak cucu berbeda jauh dengan yang original. Untuk konteks individual, seseorang mungkin akan mampu mencapai hasil gemilang pada item khusus di masa sekarang, namun pada kenyataannya sukses yang dicatatkan merupakan bagian kredibilitas praktek generasi terdahulu. Dengan kata lain, tidak seorang pun berhak menuntut ataupun menjadikan hanya untuk diri sendiri nilai universal yang berhasil dibuat, walaupun ia memang bertanggung jawab terhadap obyek nilai tersebut.

Tanggapan Wenat terhadap kritik teori nasionalis memperkuat posisi transhistoris kelompok yang telah menyandang hak kedaulatan teritorial; bahwa tidak ada diskontinuitas karena perbedaan generasi, dan yang terpenting adalah masing-masing generasi bukan hanya menikmati nilai yang ditambahkan, tetapi seluruh elemen nilai secara turun temurun. Wenat (2008: 28-31) menambahkan bahwa satu prasyarat mutlak agar hak teritorial kelompok tetap boleh diwariskan kepada generasi mendatang, tanpa perlu bersusah payah membela tanah dari klaim pihak asing, adalah dengan memastikan agar generasi penerus tetap tinggal di wilayah asal secara konsisten. Untuk itulah dibutuhkan penambahan nilai universal secara terus menerus, transfer pengalaman dan pengetahuan yang bermanfaat. Secara alamiah setiap kebudayaan melakukan hal demikian. Namun tidak semua dari mereka berhasil mewariskan kekuatan dan kekuasaan teritorial yang telah dimiliki kepada anak cucu. Sekalipun demikian teoritisi nasionalis lain, seperti Miller (2012:260-261), mengklaim bahwa kebudayaan kelompok tidaklah kaku. Kelompok yang terpaksa meninggalkan daerah asal akan dengan sendirinya mencari dan menemukan cara untuk bertahan hidup; dengan berusaha untuk meningkatkan nilai kulural dan/atau nilai universal baru di tempat yang baru. 
Mereka yang menganut pandangan kesetaraan global (global equality) masih mempercayai kalau generasi sekarang yang menikmati keistimewaan teritorial karena faktor genetis harus dikenakan pajak, walaupun mereka tetap dibiarkan memegang kontrol atas teritori (Ivison 2002: 71-74). Ide kesetaraan global mengandaikan bahwa Bumi adalah milik bersama, dimana pemanfaatan sumber daya alam pun harus dilakukan dengan mekanisme kebersamaan. Idealisme kosmopolitan ekonomis sebagaimana diungkapkan oleh ben Hendrix (2008:64-65) menyerang teori nasionalis karena sifatnya yang kultursentris dan egois. Menjawab kritik kaum kosmopolitan, pengusung teori nasionalis seperti Miller (2011: 104) mengatakan bahwa '...jika sebuah nilai harus mencakup unsur universal dan kultur spesifik secara bersamaan, maka akan muncul kesulitan untuk membuat ukuran (metric) yang akan dapat mengelola bentuk-bentuk nilai yang berbeda secara proporsional'. Dengan kata lain, kegiatan tersebut tidak masuk akal bagi mereka yang meyakini validitas teori nasionalis.

Sampai di sini, semakin jelas bahwa esensi teori nasionalis yang berbasis argumen peningkatan nilai material tanah memberi jawaban yang tegas terhadap pertanyaan siapa yang paling berhak mendapat, menjalankan serta mewariskan hak kedaulatan teritorial dengan menyebut satu kriteria fundamental; kelompok yang mengokupasi suatu tempat dan berhasil mengusahakan perbaikan nilai tempat tingga lmereka sepanjang waktu. Teori nasionalis menekankan pada hak kedaulatan teritorial hanya bagi mereka yang terlegitimasi di suatu wilayah. Sebaliknya, teori nasionalis tidak membenarkan; 1) suatu kelompok mengklaim kedaulatan teritorial kelompok lain hanya karena mereka telah berhasil membuat tanah yang diklaim menjadi lebih bernilai, cara ini tidak punya koneksi dengan tujuan awal peningkatan nilai dan kedaulatan atas wilayah, sekalipun itu adalah satu-satunya metode untuk menikmati kreasi yang sudah dibuat, dan 2) suatu kelompok tidak bisa menuntut kedaulatan teritorial melalui imperialisme dan pengusiran penduduk asli.

\section{Kedaulatan teritorial: hak atau tanggung jawab?}

Tantangan terbesar yang dihadapi oleh negara berdaulat sebagai pemegang hak teritorial yang absah adalah agenda yang disebut dengan perjuangan hak-hak individual (the struggle for individual rights). Secara konseptual gagasan tentang hak individual berkembang sebagai respon kritis terhadap teori statis utilitarian serta elaborasi teori nasionalis, yang menghasilkan postulat kedaulatan sebagai tanggung jawab (sovereignty as responsibility). Popularitas diskursus kedaulatan sebagai tanggung jawab mencapai puncak setelah berakhirnya Perang Dingin, yang ditandai dengan peningkatan signifikansi isu global nonkonvensional, seperti keamanan manusiawi (human security), hak azasi manusia, konflik berlatar identitas kultural, dan fundamentalisme keagamaan. Manifestasi konsep kedaulatan sebagai tanggung jawab teramati dalam kebijakan dan aksi intervensi kemanusiaan (humanitarian intervention) dan tanggung jawab melindungi (the responsibility to protect/R2P).

Teori kontrak sosial antara negara dan individu warga negara, seperti dikemukakan oleh Thomas Hobbes, menganggap kedaulatan bersumber dari individu warga negara. Negara yang direpresentasikan oleh pemerintah diberi mandat kekuasaan (power) dalam rangka mewujudkan tanggung jawab menciptakan rasa aman dan kesejahteraan bagi warga negara. Jika tanggung jawab negara tidak dipenuhi, maka rakyat berhak mencabut kedaulatan yang dimiliki oleh pemerintah (Bellamy \& Drummond 2011:180). Teori kontraktual Hobbes mendapat afirmasi ketika terjadi revolusi di Perancis dan Amerika Serikat, yang kemudian mencetuskan konsep hak azasi manusia dan kedaulatan populis/demokrasi (Bukavansky 2002). Setelah Perang Dunia II, gagasan kedaulatan rakyat menjadi salah satu pilar politik negara dan dunia modern.

Ide kedaulatan sebagai tanggung jawab mendapat momentum tepat pada dekade 1990an seiring merebaknya konflik internal di berbagai kawasan dunia. Perang sipil yang brutal dengan korban jiwa dan materi besar dibarengi oleh fenomena kegagalan negara-negara -khususnya di Benua Afrikauntuk memulihkan ketertiban sosial dan kondisi ekonomi warga negara. Wakil khusus Perserikatan Bangsa Bangsa (PBB) yang membidangi masalah korban perang, Francis Deng dan Roberta Cohen, mengkritik sikap pasif masyarakat internasional terhadap ekspansi dampak negatif kekerasan massal di Afrika. Mereka kemudian mengusulkan suatu tindakan bersama (collective action) untuk melindungi dan menyelamatkan masyarakat sipil dari bahaya genosida, pembasmian etnis, dan kejahatan perang (Deng 2004: 20). 
Deng dan Cohen menyusun kerangka referensi kedaulatan sebagai tanggung jawab melindungi/R2P ke dalam tiga elemen. Pertama, tidak ada negara berdaulat yang menolak untuk melindungi warga negara. Kedua, bila negara berdaulat ternyata tidak mampu melindungi warga negara, maka yang semestinya dilakukan ialah mengundang atau memberi jalan bagi pihak asing yang berminat dan sanggup untuk membantu. Cara ini tidak perlu dianggap sebagai pengingkaran terhadap kedaulatan nasional, sebab negara sebagai anggota masyarakat internasional memiliki hak dan kewajiban menegakkan keamanan bagi warga negara (Deng \&Cohen 1998: 275). Yang menjadi pertanyaan adalah bagaimana bila negara berdaulat tidak mau meminta bantuan pihak luar, karena bertahan pada prinsip non-interference yang absah menurut Piagam PBB. Secara filosofis konsep R2P merefleksikan upaya liberalisasi mazhab kedaulatan teritorial dalam politik antar bangsa.

Menanggapi persoalan di atas -terutama didukung oleh kasus intervensi kemanusiaan NATO di Kosovo- Deng dan Cohen yang kemudian direstui oleh Sekretaris Jenderal PBB Kofi Annan mengajukan rekonsiliasi antara konsep kedaulatan sebagai hak teritorialitas untuk mengatur diri sendiri (sovereignty as the right to self-rule) dan perlindungan terhadap HAM serta kemerdekaan individu (Annan 1999: 50). Usulan Annan, Deng dan Cohen diwujudkan oleh Pemerintah Kanada kedalam sebuah Komisi Internasional untuk Intervensi dan Kedaulatan Negara (The International Commission on Intervention and State Sovereignty, ICISS). Pertemuan ICISS menghasilkan rekomendasi penguatan dan aplikasi nyata prinsip R2P sebagai salah satu kaidah global menjelang abad ke-21 (ICISS 2001). Dalam World Summit September 2005 negara-negara anggota PBB yang hadir pada sidang Majelis Umum bersedia mengadopsi ide kedaulatan sebagai tanggung jawab (United Nations 2005). Namun belum ada kesepakatan mengenai kriteria intervensi; kapan, siapa, dan bagaimana intervensi hendak dilakukan. Satu persoalan yang juga belum tuntas dibahas ialah bagaimana menyikapi hak veto oleh anggota permanen Dewan Keamanan; apakah situasi genting yang membahayakan keamanan warga suatu negara gagal (failed state) harus dikompromikan demi kepentingan politik aktor kuat tertentu.

Sekalipun demikian kemunculan konsep kedaulatan sebagai tanggung jawab bermakna politik dan legal yang penting. Alex Bellamy dan Catherine Drummond (2011: 284) mencatat empat signifikansi kedaulatan sebagai tanggung jawab negara. Pertama, prinsip tanggung jawab tidaklah lemah di hadapan kedaulatan dengan norma non-interference, sebab pada dasarnya yang merupakan kewajiban fundamental negara adalah melindungi warga negara. Tanggung jawab melindungi selalu berada di tangan pemerintah negara berdaulat, sementara negara-negara lain hanya berfungsi membantu melalui proses yang legitimate menurut PBB. Kedua, sasaran implementasi tanggung jawab negara adalah melindungi keamanan manusiawi dari bahaya kejahatan seperti genosida, pembasmian etnis, dan pelanggaran HAM yang kesemuanya telah memiliki definisi jelas dan rujukan yang eksis dalam hukum internasional. Ketiga, intervensi dalam konteks R2P tidak mengubah karakteristik dasar tanggung jawab dan hak tiap negara, tetapi merupakan instrumen yang dipilih oleh masyarakat internasional dalam rangka menegakan kedaulatan individu warga negara. Keempat, sebagai luaran dari pertemuan terbesar para kepala negara dan pemerintahan di dunia, persetujuan tentang konsep kedaulatan sebagai tanggung jawab memiliki pesan politik yang kuat, yaitu bagaimana masyarakat internasional mengakomodasikan norma di tingkat global dengan tradisi dan sistem lokal.

Menurut Alex Bellamy dan Paul Williams (2011:825-848) terdapat empat karakteristik dasar kekinian kedaulatan sebagai tanggung jawab setelah aksi internasional di Pantai Gading dan Libya, yakni; 1) intervensi dibenarkan dengan diskursus perlindungan terhadap kemanusiaan; 2) otorisasi oleh Dewan Keamanan PBB untuk tindakan militer di Pantai Gading dan Libya merupakan terobosan atas prinsip nominal intervensi kemanusiaan yang mempersyaratkan persetujuan negara tuan rumah; 3) organisasi regional - spesifik pada kasus Afrika - telah memainkan peran krusial dalam membingkai isu dan solusi krisis, sehingga menjadi mitra sukses Dewan Keamanan dalam proyek tanggung jawab melindungi; dan 4) masyarakat internasional telah mengekspresikan sebuah komitmen untuk bekerjasama melalui Dewan Keamanan dalam merespon krisis kemanusiaan. 


\section{Simpulan}

Kasus campur tangan masyarakat internasional di Pantai Gading 2010 dan Libya 2011 menunjukkan adanya kesadaran, kesiapan dan aplikasi yang lebih konkrit agenda perlindungan warga negara dari kekerasan yang dilakukan rezim yang sedang berkuasa. Pertanyaan yang menyoal relevansi intervensi kemanusiaan pasca keterlibatan pasukan multinasional di Libya bukan lagi apakah tindakan campur tangan asing harus dijalankan atau tidak, melainkan kapan waktu yang tepat dan bagaimana cara yang jitu untuk turun tangan. Krisis Pantai Gading dan Libya mendemonstrasikan moral politik dan keputusan kolektif dengan argumentasi dan legitimasi yang kuat.

\section{Daftar Pustaka}

Annan K (1999) Two concepts of sovereignty. The Economist 352 (8137) 49-50.

Austin-Smith B (2003) Sovereignty and culture. Canadian Dimension 37(2) 39-40.

Baeker D (1997) The meaning of culture. Thesis Eleven 51(1) 37-51.

Bellamy AJ \& C Drummond (2011) The responsibility to protect in Southeast Asia: between noninterference and sovereignty as responsibility. The Pacific Review 24(2) 179-200.

Bellamy AJ \& PD Williams (2011) The new politics of protection Cote d'Ivoire, Libya and the responsibility to protect. International Affairs 87(4) 825-50.

Branch J (2011) Mapping the sovereign states: technology, authority, and systemic change. International Organization 65(1) 1-36.

Buchanan AE (2004) Justice, legitimacy, and self-determination: moral foundations for international law Oxford. Oxford: University Press.

Bukavansky M (2002) Legitimacy and Power Politics the American and French Revolutions in International Political Culture. Princeton: Princeton University Press.

Clunan A \& H Trinkunas (2010) Ungoverned Spaces Alternatives to States in Era of Softerned Sovereignty. Palo Atto: Stanford University Press.

Deng F M (2004) The impact of state failure on migration. Mediterranean Quarterly 15(4) 16-36.

Deng FM \& R Cohen (1998) Masses in Flight the Global Crisis of Internal Displacement. Washington DC Brookings Institution.

Enabulele AO (2010) Humanitarian intervention and territorial sovereignty the dilemma of two bed fellows. The International Journal of Human Rights 14(3) 407-424.

Etherington J (2010) Nationalism, nation, and territory. Annals of the Association of American Geographers 33(10) 1814-1842.

Foley R (2007) Plato's undividable line contradiction and method in Republic VI. Journal of the History of Philosophy 46 (1) 1-23.

Gillette H \& Patrinos HA (2005) Indigenous Peoples, Poverty, and Human Development in Latin America. Basingstoke: Palgrave Macmillan.

Hainsworth P et al (2000) The East Timor Question Struggle for Independence from Indonesia. London: I. B. Tauris \& Co.

Hendrix B (2008) Postcolonial Liberalism. Oxford: Oxford University Press.

ICISS (2001) The Responsibility to Protect. Ottawa: IDRC.

Ivison D (2002) Oenership, Authority, and Self-Detemination University Park PA Pennsylvania University Press.

Kaufman A (1999) Welfare in the Kantian State. New York Oxford University Press.

Knowles D (2001) Political philosophy London Routledge.

Kwok-bun C \& Wai-wan C (2010) The return of the native globalization and the adaptive responses of transmigrants. World Futures 66(6) 696-434.

Lee D \& Smith N (2010) Small state discourses in the international political economy. Third World Quarterly 37(1) 1091-1105.

Lee W (2015) Post-Suharto Democratisation and the Obstacles to a Security Community between Australia and Indonesia $\mathrm{PhD}$ Thesis University of Western Australia.

McCormick J (2007) The European Superpower. New York: Palgrave Macmillan.

Miller D (1995) On Nationalism. Oxford: Clarendon. 
Miller D (2011) Property and territory Locke, Kant, and Steiner. Journal of Political Philosophy 19(1) 90-109.

Miller D (2012) Territorial rights concept and justification. Political Studies 60(2) 252-268.

Moore M (1998) National Self-determination and Sucession. Oxford: Oxford University Press.

Nine C (2008) A Lockean Theory of Territory. Political Studies 56(1) 140-165.

Raz J (2001) Value, respect, and attachment. Cambridge: Cambridge University Press.

Reuveny R, Maxwell JW \& Davis J. (2011) On conflict over natural resources. Ecological Economics 70(4) 698-712.

Rutter M \& Tienda (2005) Ethnicity and Causal Mechanisms. Cambridge: Cambridge University Press.

Sandelind C (2015) Territorial rights and open borders. Critical Review of Social and Political Philosophy 18(5) 487-507.

Simmons AJ (2001) On the territorial rights of states. Philosphical Issue 11(1) 300-326.

Smith AD (1999) Myths and Memories of a Nation. Oxford: Oxford University Press.

Stilz A (2011) Nations, states and territory. Ethics: 121(3) 572-607.

United Nations (2005) World Summit Outcome Document. New York: UN Publishing Unit.

Valeriano B \&J V Benthuysen (2012) When states die: geographic and territorial pathways to state death. Third World Quarterly 33(7) 1165-1189.

Vandengeest P \&A Unno (2012) A new extraterritoriality aquaculture certification, sovereignty, and empire. Political Geography 31(6) 358-367.

Wenat L (2008) Property rights and the resource curse. Philosophy \& Public Affairs 36(1) 2-32. 